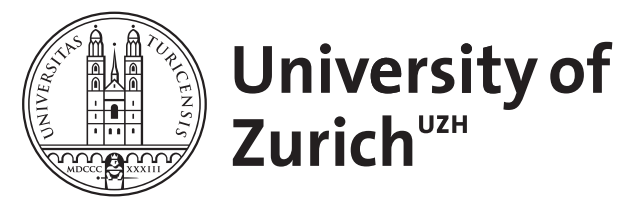

\title{
Numeracy and the impact of high food prices in industrializing Britain, 1780-1850
}

\author{
Baten, Jörg ; Crayen, Dorothee ; Voth, Hans-Joachim
}

\begin{abstract}
Using census-based data on the ability to recall one's age, we show that low levels of nutrition impaired numeracy in industrializing England, 1780 to 1850: cognitive ability declined among those born during the Napoleonic wars. The effect was stronger in areas where grain was expensive and relief for the poor, an early form of welfare support was limited. Nutritional shortages had a nonlinear effect on numeracy, with, severe shortages impairing numeracy more. Nutrition during childhood also mattered for labor market outcomes: individuals born in periods or counties with low numeracy typically worked in occupations with lower earnings.
\end{abstract}

DOI: https://doi.org/10.1162/REST_a_00403

Posted at the Zurich Open Repository and Archive, University of Zurich ZORA URL: https://doi.org/10.5167/uzh-100551

Journal Article

Originally published at:

Baten, Jörg; Crayen, Dorothee; Voth, Hans-Joachim (2014). Numeracy and the impact of high food prices in industrializing Britain, 1780-1850. The Review of Economics and Statistics, 96(3):418-430.

DOI: https://doi.org/10.1162/REST_a_00403 


\title{
NUMERACY AND THE IMPACT OF HIGH FOOD PRICES IN INDUSTRIALIZING BRITAIN, 1780-1850
}

\author{
Jörg Baten, Dorothee Crayen, and Hans-Joachim Voth*
}

\begin{abstract}
Using census-based data on the ability to recall one's age, we show that low levels of nutrition impaired numeracy in industrializing England, 1780 to 1850: cognitive ability declined among those born during the Napoleonic wars. The effect was stronger in areas where grain was expensive and relief for the poor, an early form of welfare support was limited. Nutritional shortages had a nonlinear effect on numeracy, with, severe shortages impairing numeracy more. Nutrition during childhood also mattered for labor market outcomes: individuals born in periods or counties with low numeracy typically worked in occupations with lower earnings.
\end{abstract}

\section{Introduction}

$\mathrm{S}$ UBSTANTIAL evidence in both developing countries and the developed world shows that poor nutrition in early childhood has a negative effect on physical and mental health later in life, educational attainment, and labor market success. Medical research using controlled experiments and twin studies suggests that sudden shocks to nutrient availability have marked effects (Richards et al., 2002; Lucas, 1998). Randomized control experiments in the developing world and quasi-random variations in nutrition among Muslims in developed countries point in the same direction (Vermeersch \& Kremer, 2004; Almond \& Mazumder 2011; Currie, 2009).

At the same time, evidence in favor of aggregate shocks having a major effect is surprisingly rare. While disease outbreaks can have strongly adverse consequences (Almond, 2006), economic dislocation has rarely been shown to affect cognitive and health outcomes in a consistent fashion. Not even the U.S. Dust Bowl seems to have affected heights, chronic disease, or body mass (Cutler, Miller, \& Norton, 2007). Stein and Susser (1976) examined the Dutch hunger winter in 1944-1945. Retreating German forces left part of the population starving for five to six months. Those affected in utero or just born showed no systematic reduction of $\operatorname{cog}$ nitive ability later in life, perhaps because the insult could be compensated shortly thereafter. ${ }^{1}$ In contrast, studies of Zimbabwe and China have found some negative consequences of

Received for publication December 4, 2011. Revision accepted for publication March 4, 2013.

* Baten and Crayen: Tübingen University; Voth: U Zurich and UBS Center.

An earlier working paper version was circulated under the title "Poor, Hungry, Ignorant." We thank the editor, Gordon Hanson, as well as two anonymous referees for their suggestions and advice. Seminar audiences at Princeton, Stanford, MIT, UPF, and the LSE helped us with their comments, and Pol Antràs, Paula Bustos, Fernando Broner, Anne Case, Angus Deaton, Jordi Galí, Tim Leunig, Joel Mokyr, Thijs van Rens, and Rick Steckel provided valuable feedback. Voth thanks the European Research Council for support through ERC-ADG \#230515.

A supplemental appendix is available online at http://www.mitpress journals.org/doi/suppl/10.1162/REST_a_00403.

${ }^{1}$ This is despite reductions in birth weight (Stein \& Susser, 1976). At the same time, there is evidence that the cohorts affected suffered from greater incidence of heart disease and personality disorders (Neugebauer, Hoek, \& Susser 1999). civil war and famine (Alderman, Hoddinott, \& Kinsey, 2006; Chen \& Zhou, 2007). The disconnect between microstudies and examinations in the aggregate is an important puzzle.

In this paper, we examine the decline in cognitive ability during a nationwide quasi-experiment: the Napoleonic wars produced to a nutritional crisis in England. A combination of a stopped imports from the Continent and poor harvests led to markedly higher grain prices in some years. Among Englishmen born after 1790, numeracy declined sharply. We derive a measure of cognitive ability by constructing a new data set on misreported ages in England, 1780 to 1850, based on census data, and analyze differences-in-differences. As grain prices rose by up to $100 \%$ after 1790 , the number of wrongly reported ages doubled. The decline in numeracy also differed by region. England had an early and generous form of poor relief (Mokyr, 1993), but some parishes were more supportive than others. We show that income support for the poor helps to explain cross-sectional variation in cognitive skill: counties with generous payments saw the smallest declines in numeracy when prices were high. Price spikes had adverse effects that increased exponentially; they were also greater in areas of economic vulnerability.

We use data on age heaping - the number of people who wrongly report their age as a multiple of five in the censusto construct a simple measure of cognitive ability in the past. Self-reported ages often show a tendency for people to round off to the nearest multiple of 5 or 10 (Mokyr, 1983; Myers, 1976). Age heaping can serve as a good proxy of numerical skill. $^{2}$ Today, numeracy predicts both wages and employment. ${ }^{3}$ We show that numeracy is correlated with stature in many historical samples and argue that this reflects the adverse effects of malnutrition on cognitive development. We also show that cognitive ability and age misreporting are positively associated among the elderly today.

Nutrition in the past was often poor. Average heights were low. Adult males born before 1850 often measured less than 170 centimeters, below the tenth percentile of the US population today. ${ }^{4}$ Stature is a good indicator of cumulative net nutrient intake during the growing years (Steckel, 1995, Komlos, 1989). While short-term nutritional deficits

\footnotetext{
${ }^{2}$ Roman tombstones, for example, show high rates of age heaping (Duncan-Jones 1990). Gradual changes in heaping over longer periods can reflect a number of factors, such as schooling, the importance of administrative procedures relying on age, and evolving cultural norms. These factors are unlikely to explain abrupt changes over short periods. Short, sharp shocks to numeracy are more likely to reflect environmental factors.

${ }_{4}^{3}$ Rivera-Batiz (1992).

${ }^{4}$ This is the average height of eighteenth-century Dutchmen and Norwegians, who today are among the tallest populations on earth (Fogel, 1994).
} 
can be compensated through so-called catch-up growth, sustained shortfalls affect terminal heights. ${ }^{5}$

The consequences of widespread stunting are less clear. Waaler (1984) demonstrated that height and weight were good predictors of individual mortality risk. Fogel (1994) argued that low calorie intake drastically curtailed output per capita in the past. What has remained unexplored are the consequences of massive malnutrition in the past for cognitive development and educational attainment. Lack of data has so far stood in the way of such research. Standard measures of cognitive ability, such as IQ or math test scores, are not available for the more distant past.

To substantiate the link with nutrition, we connect age heaping with evidence on stature. Numeracy, as captured by age heaping, in part reflects the influence of nutrition; it fell the most in counties that witnessed the biggest declines in height. Finally, we show that those affected by the food crisis of the Napoleonic years, and especially those born in counties with limited poor relief, were more likely to sort into occupations with lower wages. Thus, malnutrition in the past directly led to limited cognitive development, resulting in poor labor market outcomes.

Related literature includes work on nutrition and cognitive development, which suggests that nutrient intake in utero and in childhood affects intelligence directly. Our conclusions are in line with research showing that nutritional status is correlated with cognitive ability and labor market success. Persico, Postlewaite, and Silverman (2004) show that heights have considerable explanatory power for wages, and attribute the effect to differential socialization (e.g., through more active participation in school sports teams). Case and Paxson (2008) instead argue that the effect largely reflects the superior cognitive scores of the taller and better nourished. ${ }^{6}$ We discuss this literature in more detail in section II.

Compared to earlier studies, this paper makes a number of contributions. We are the first to document a strong negative effect of an aggregate economic shock on numeracy. We also show that in eighteenth-century Britain, early welfare systems could mitigate the impact of hard times. Finally, we demonstrate that wartime shocks to nutritional status in childhood had negative consequences for labor market outcomes many decades later.

Our results build on recent anthropometric research that has sought to measure nutrition in the past, mainly based on height (Steckel, 1995; Fogel, 1994). Other related research includes work on human capital formation in industrializing Britain (Mitch, 1998; Schofield, 1973). Finally, our findings have an indirect bearing on research into the origins of

\footnotetext{
${ }^{5}$ Because Europeans' genetic composition has changed little in the past two centuries, historic heights must reflect severe chronic malnutrition in the more distant past.

${ }^{6}$ Komlos (1989) argued that nutrition mattered at the opposite end of the skill spectrum as well. He observed that many innovators of the Industrial Revolution in the United Kingdom were born during the good times of the 1730s, when food prices were low.
}

accelerating growth after 1850 . One class of unified growth models (Galor \& Weil, 2000) has aimed to join humancapital-based interpretations with models of fertility choice. In this class of models, more investment in the skill of the workforce was crucial for the transition to self-sustaining growth. While we do not examine these arguments directly, we document how nutrition constrained a key dimension of premodern human capital: numeracy.

Section II reviews the literature on the link between IQ, malnutrition, and labor market performance. Section III describes our preferred measure of numeracy based on age heaping, and section IV discusses the data we use. Our results are presented in section V. In section VI, we discuss our results in context, and section VII concludes.

\section{Nutrition, Cognitive Ability, and Occupational Outcomes}

In this section, we briefly review the literature linking nutrition, cognition, educational attainment, and labor market outcomes. There is strong evidence that childhood health and nutrition matter for cognitive ability, education, and success in the labor market later in life. Experiments suggest that nutrition in childhood influences intellectual ability. Low birth weight in humans predicts lower cognitive scores (Richards et al., 2002). ${ }^{7}$ Malnutrition between the ages of 1 month and 16 months is a strong predictor of poor cognitive outcomes (Lloyd-Still, 1976). In one study of preterm infants, the protein content of the diet was varied on a random basis (Lucas, 1998). Children receiving poorer diets showed markedly lower mental development scores and psychomotor scores at the 18-month follow-up than the control group. These effects could still be detected as late as at age 7.5, when IQ scores were significantly lower. Vermeersch and Kremer (2004) show that a protein-enriched diet given to preschool children in Kenya improved both participation in educational activities and cognitive scores in schools with experienced teachers. In addition, poor in utero conditions, as reflected by low birth weight, are systematically associated with a greater risk of mental disease (Linnet et al., 2006).

The positive correlation of heights and cognitive scores also suggests that malnutrition can adversely affect intellectual development. Just like height, intelligence of individuals is in part determined by parental genes and partly by environmental factors. Paxson and Schady (2007) find that in a large sample from Ecuador, test scores for shorter children are significantly lower than for taller ones. Richards et al. (2002) use data on IQ scores and height for a large British postwar sample, and find that the variables are strongly and positively correlated. In particular, maximum height gain during early childhood and the timing of the adolescent growth spurt predict cognitive ability.

\footnotetext{
${ }^{7}$ Currie and Hyson (1999) demonstrate that low birth weight is associated in British post-World War II data with lower employment probability, lower IQ scores, and lower income. Case, Fertig, and Paxson (2005) show that this effect is still visible for subjects at age 42.
} 
There is also some evidence that rising IQ scores in developed countries reflect improving nutrition (Lynn \& Vanhanen, 2002). ${ }^{8}$ Genetic factors do not dominate: twin studies suggest that genetic influences cannot explain the correlation between heights and cognitive ability (Magnusson, Rasmussen, \& Gyllensten 2006). ${ }^{9}$

While sensitivity is great in utero and in early childhood (Heckman, 2007), nutrition during the second decade of life also appears to have a major effect. Recent studies found a clear cumulative effect of persistent exposure to malnutrition and poverty. The longer a child's nutritional, emotional, and educational needs are not satisfied, the greater are his or her cognitive deficits (Paxson \& Schady, 2007). There also appears to be little catch-up in cognitive scores: the effects of a disadvantageous early environment still appear into late middle age and beyond (Abbott et al., 1998; Richards et al., 2002; Richards \& Wadsworth, 2004).

Cognitive ability also has an effect on labor market outcomes. Zax and Rees (2002) show that intelligent members of the workforce earn substantially more. Heckman (1995) finds IQ to be one important predictor of wages. Using British post-World War II data, Case and Paxson (2008) show that the correlation between height and earnings disappears when one controls for cognitive scores. This suggests that much of the observed association of stature with earnings may simply reflect the effect of nutrition on intellectual development. ${ }^{10}$

A large literature demonstrates that childhood nutrition matters for cognitive ability, education, and success in the labor market in later life. We now turn to documenting these links for the case of industrializing Britain.

\section{Numeracy}

Age heaping has been used as an indicator of numeracy in a number of studies. Bachi (1951) and Myers (1976) show that across countries and within them, richer, more educated populations are less prone to show age heaping. Historical applications include the work of Herlihy and Klapisch-Zuber (1978) on fourteenth-century-Florence, Mokyr (1983) on selectivity bias among Irish emigrants, and DuncanJones (1990) on the Roman Empire. Over the very long run, numeracy as proxied by age heaping varies strongly with income and is highly correlated with literacy (Clark, 2007; A'Hearn, Baten, \& Crayen, 2009).

\footnotetext{
${ }^{8}$ A randomized experiment in Guatemala demonstrates that protein supplements can produce marked improvements in cognitive ability (Pollitt et al., 1993).

${ }_{9}$ Sundet et al. (2005) argue that height and intelligence may be jointly determined by parental genes and that this accounts for approximately $30 \%$ of the observed comovement.

${ }^{10}$ An additional channel through which nutrition matters for labor market outcomes is schooling. Worm eradication in Kenya increased school attendance markedly while leaving test scores unaffected (Miguel \& Kremer, 2004)

${ }^{11}$ There is substantial evidence that the Whipple index dominates competing estimators like the Bachi measure, in particular in terms of accuracy at low levels of heaping. For an overview of different indicators, see A'Hearn, et al. (2009).
}

The most commonly used measure of age heaping is the Whipple index. ${ }^{11}$ It calculates the number of self-reported ages that are multiples of 5 relative to the number expected with a uniform distribution of ages:

$$
W=100 \frac{\sum\left(n_{25}+n_{30}+n_{35}, \ldots, n_{60}\right)}{\frac{1}{5} \sum_{i=23}^{62} n_{i}} .
$$

The range of ages has to be chosen so as to include the same number of ages for each terminal digit (in this case, 23 to 62 ). The index ranges from 0 to 500. Accordingly, a Whipple index of 0 (500) implies no (only) ages ending in multiples of 5. At 100, it would imply that exactly $20 \%$ of the population report ages ending in multiples of 5 , the expected frequency in a population without heaping.

We use the age statements of the censuses of 1851 and 1881 and organize these by birth decade and birth county, because basic numeracy is mostly determined in the first decade of life (details in appendix $\mathrm{A}$ in the online supplement). Figure 1 illustrates the phenomenon by plotting the age distribution in two English counties, Somerset in the census year 1851 (lower panel) and Sussex in 1881 (upper panel). In Somerset, heaping was strong: the Whipple score is 125 . In Sussex, age heaping was also present, but the ratio between the number of persons reporting a multiple of five and the expected number is considerably lower (Whipple of 109).

That age reporting in the U.K. censuses was not fully accurate has been known for some time. ${ }^{12}$ The General Report for the 1891 census argued that "a very large proportion of persons, not improbably the greater number of adults, do not know their precise ages and only report it approximately." 13 Various other studies have examined age recording between two or several nineteenth century British censuses. They found that $2 \%$ to $11 \%$ were off by more than two years (Higgs, 1989; Tillot, 1972). Adjustments were as likely to be up as down, suggesting genuine mistakes. ${ }^{14}$

In addition, we use a measure of misreporting of ages in the spirit of the Myers index. For each county, we fit a linear trend to the distribution of reported ages. Then, for each birth year, we obtain a measure of inaccurate age reporting as the absolute value of the residual of the regression. Both over- and underreporting age frequencies will influence the estimate of inaccuracy. While the decade-based measure of the Myers index is generally less robust as an indicator of numeracy than the decade-specific Whipple index (A'Hearn

\footnotetext{
12 Apart from the heading of the appropriate column in the household schedule which said "Age [last birthday]," no general instruction was given to households on how to report their age.

${ }^{13}$ Census (1891, p. 27). Thomson (1980) traced individuals' selfreported ages across the 1861,1871 , and 1881 censuses. He found that for both men and women, the correct age (found by adding 10 or 20 to the earlier reported age) was given by only $38 \%$ to $64 \%$ of respondents aged 60 and over. Up to $30 \%$ gave answers that were wrong by more than two years.

${ }^{14}$ As late as 1951 , only $94 \%$ of men and $64 \%$ of women reported their ages correctly (Census, 1958, p. 36).
} 

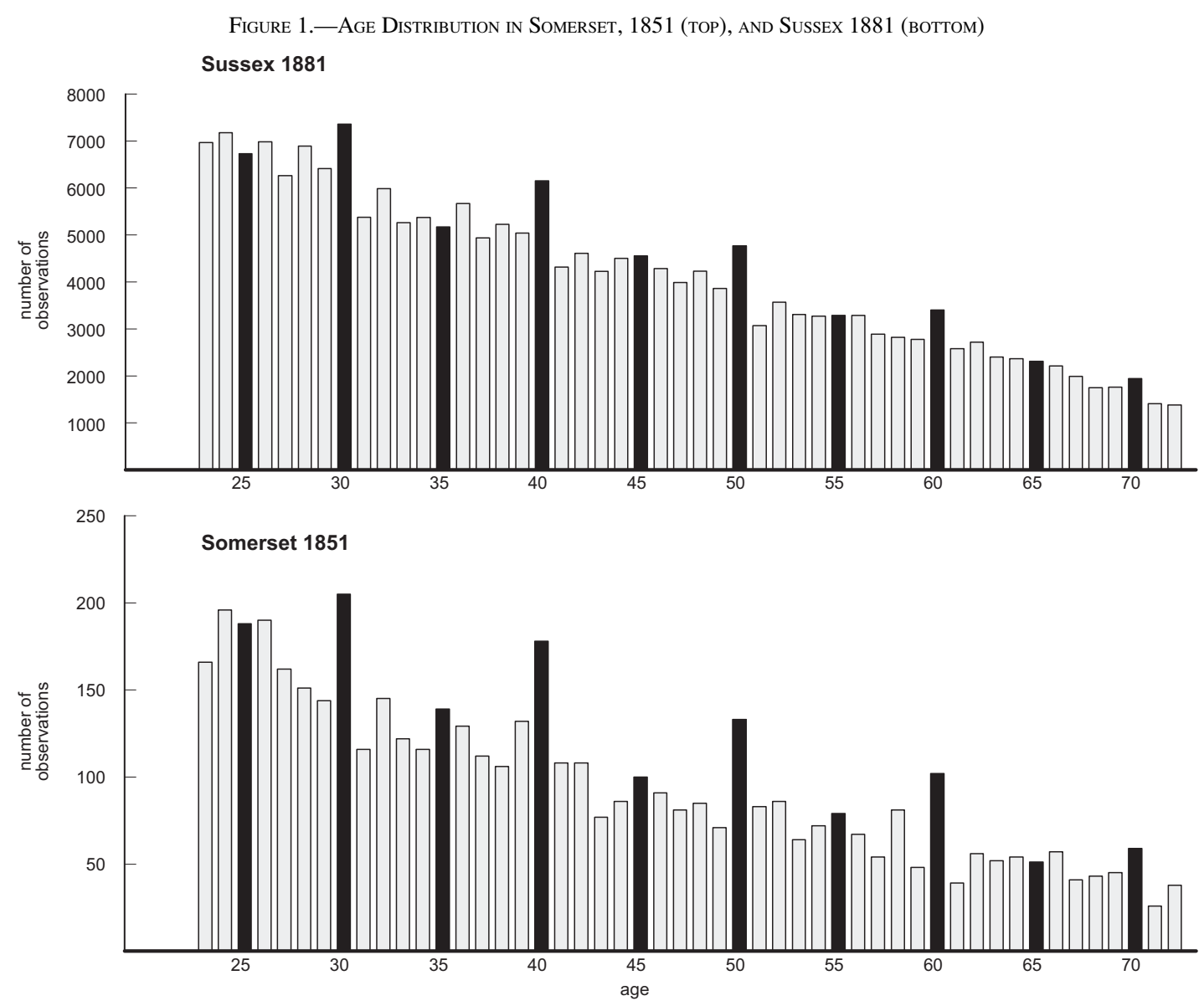

et al., 2009), we will use this indicator to exploit short-term variations in age misreporting.

It could be argued that the ability to recall one's age correctly is indicative of schooling, the bureaucratization of life, and changing cultural norms rather than of cognitive development. However, where it varies considerably over short periods, it is less likely to reflect cultural norms and administrative procedures. Since the use of age and birth date to identify individuals and the prevalence of schooling has generally been on the rise over the past three centuries, there is an asymmetry in how we should interpret short-term fluctuations. Increases could be driven by, say, the introduction of compulsory schooling (in the later nineteenth century in most European countries). Where numeracy declined sharply, additional factors are likely to be at work. ${ }^{15}$

\section{Historical Background and Data}

Britain's population increased from 5.9 million in 1760 to 16.7 million in 1850 , turning the country into a net importer of food. Consequently, "food... [became] the weakest link in Britain's chain of defense" (Olson, 1963).

\footnotetext{
${ }^{15}$ To validate our method, we show in appendix $\mathrm{C}$, that in modern data from the U.S. Health and Retirement Survey (HRS), greater heaping is strongly associated with lower cognitive scores.
}

After poor harvests, grain had to be imported from the Baltic and from France (Jacks, 2011). The French Revolutionary and Napoleonic wars made the flow of grain more difficult. As both sides sought to destroy the merchant fleet of their adversary, insurance rates for shipping surged (Jacks, 2011; Mokyr \& Savin, 1976). The Continental System constituted a ban on all trade with Britain from French-controlled Europe (Davis \& Engerman, 2006). The system was at its peak in the years 1807 to 1812 . While France supplied Britain with grain in 1810 , it charged export fees that more than quadrupled the price (Jacks, 2011). ${ }^{16}$

The difficulty of importing food came at a bad time for Britain. Harvests were poor in 1795-96, 1800-1801, and the late 1810s. At their peak, prices were more than twice as high as they had been in the 1780s. While some imports continued to flow into Britain, high transaction costs limited the extent to which domestic weather shocks could be arbitraged away. Figure 2 plots the wheat price over time; it will serve as our main indicator of a nutritional crisis. The most vulnerable parts of society often did not earn wages and depended on the informal sector or on charity. The household surveys by Sir Frederick Morton Eden (1797)

\footnotetext{
16 According to some estimates, the United Kingdom imported around $15 \%$ of its total food in 1810 (Jacks, 2011).
} 


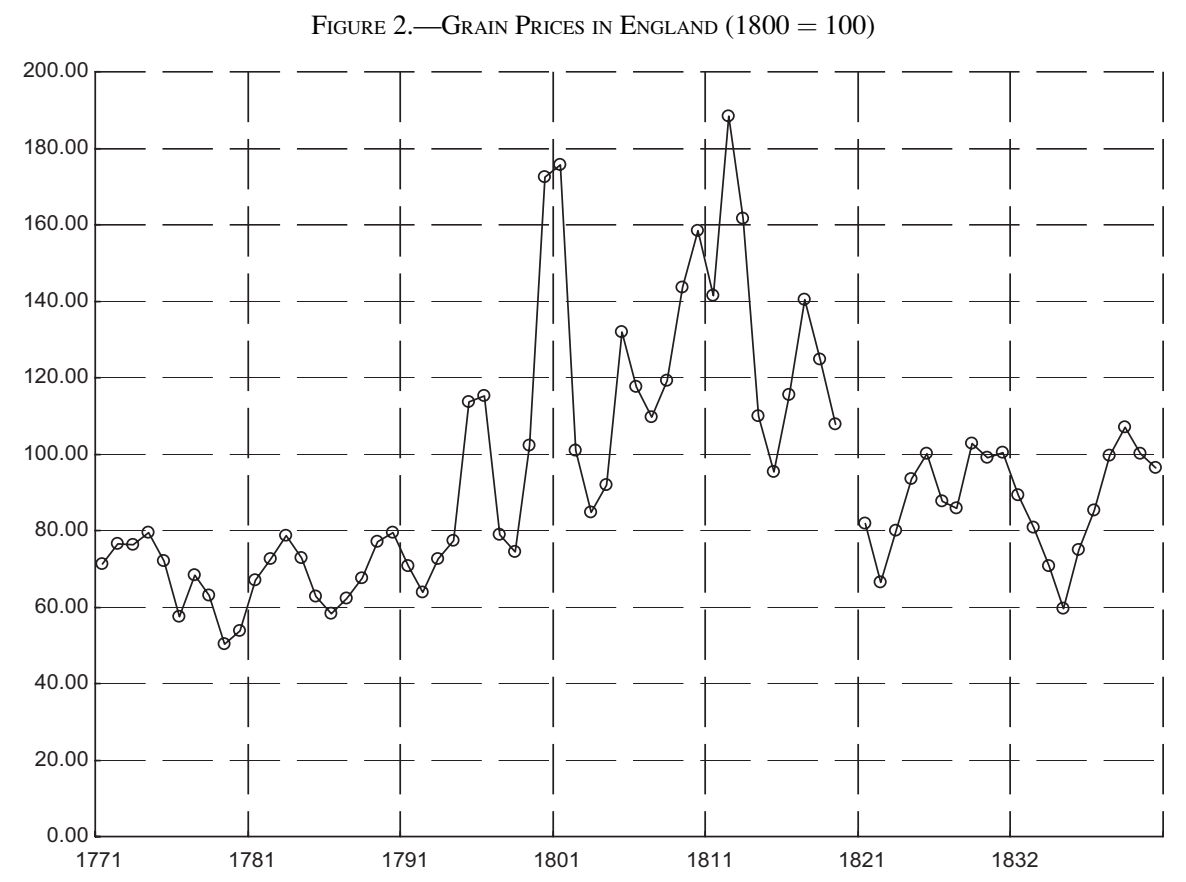

and Reverend David Davies (1795) were motivated by widespread misery: bread riots in 1795, 1800, and 1812 reflect how precarious Britain's food situation had become.

We use the average price of wheat in each county and year as the main explanatory variable. Acts of Parliament ordered the compilation of grain price data during the period1770 to $1863 .{ }^{17}$ Liam Brunt and Edmund Cannon (2013) hand-collected these data from historical prize gazettes. ${ }^{18}$ Wheat was the main staple of eighteenth- and nineteenthcentury British diets. Wheat flour alone accounted for $27 \%$ of working-class expenditure on food (figure A1 in appendix B). ${ }^{19}$ Bread, mostly wheat based, took up another $20 \%$ of the food budget. Together with oatmeal, grain-based food accounted for $60 \%$ of the food budget, or $40 \%$ of the consumer basket overall. $^{20}$

English grain markets were highly integrated; abstracting from transport cost, the no-arbitrage condition held. ${ }^{21}$ While market integration in general was high, price differences at the county level could still be substantial. For example, in 1794, the most expensive counties had prices that were $27 \%$ higher than in the cheapest ones; in 1800, the gap was

${ }^{17} 10$ George III, 31 George III, 1 and 2 George IV, 9 George IV, and 5 Victoria.

${ }^{18}$ The authors kindly made their data available to us as county-year averages. The source is described in more detail in Brunt and Cannon (2013). The data can be accessed at the ESRC data archive (http://dx. doi.org/10.5255/UKDA-SN-4383-1).

${ }^{19}$ The figure is from Voth (2003).

${ }^{20}$ To gauge the importance of wheat in particular and grain more generally, we also have to add part of the $10 \%$ spent on drink. The largest share of this would have been consumed in the form of beer, derived in large part from wheat and barley.

${ }^{21}$ The Brunt-Cannon data have already been used in recent studies of market integration (Jacks, 2011), which show how during the Napoleonic wars, regional price differences increased (as a result of, e.g., attacks on coastal shipping).
$40 \%$. This reflects the decline in market integration during the Napoleonic Wars (Jacks, 2011). As maps of grain prices in England (figure 3) show, the relative position of individual counties could also reverse quickly, with some of the cheaper areas in 1794 experiencing much higher prices in both relative and absolute terms in 1800. Coastal areas in particular, such as the one around Bristol, experienced much higher prices because transport had become so much more difficult (Jacks, 2011). ${ }^{22}$

Figure 4 shows the distribution of county grain prices by year using a box-and-whiskers plot. The lower and upper parts of the box indicate the 25th and 75th percentiles, respectively; the "whiskers" show the rest of the distribution-the 0th and 100th percentile. In most years, the range of prices is relatively small. The pairwise correlation coefficients of wheat prices are very high-typically 0.97 or above (see appendix E). However, in some years, especially in years of high grain prices, the range is dramatically wider. This is important for our study: it shows that years of nutritional crisis also coincided with lower market integration and greater region-specific shocks.

We merge our new data set on numeracy with information on the generosity of poor relief under the so-called Old Poor Law and on heights. ${ }^{23}$ Britain was one of the first countries to make support payments for able-bodied adults (outside a workhouse). The system was generous: an agri-

\footnotetext{
22 Otherwise the map displays typical regional price patterns: prices were higher near manufacturing centers (e.g., Lancashire), which could not be as easily served by cheap water transport. In contrast, the London market in 1794 benefited from cheap coastal transport. Grain prices were also higher in regions specializing on dairy farming (e.g., the English West).

${ }^{23}$ Appendix A details the data sources for Poor Law relief and British heights.
} 
Figure 3.-Wheat Price Variation in England, by County, 1794 and 1800 (in pence per bushel)

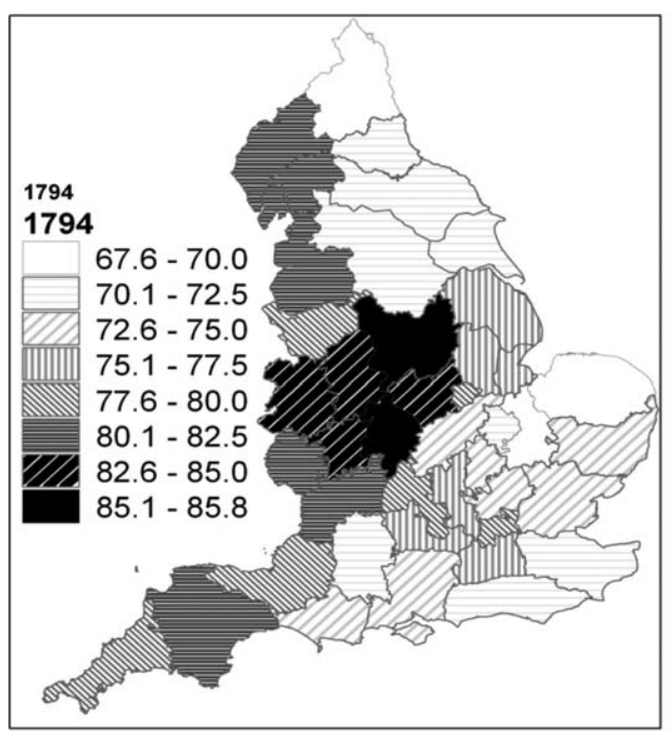

Figure 4.-Range of Wheat Prices, across Counties, by Year of Birth (IN PENCE PER BUSHEL)

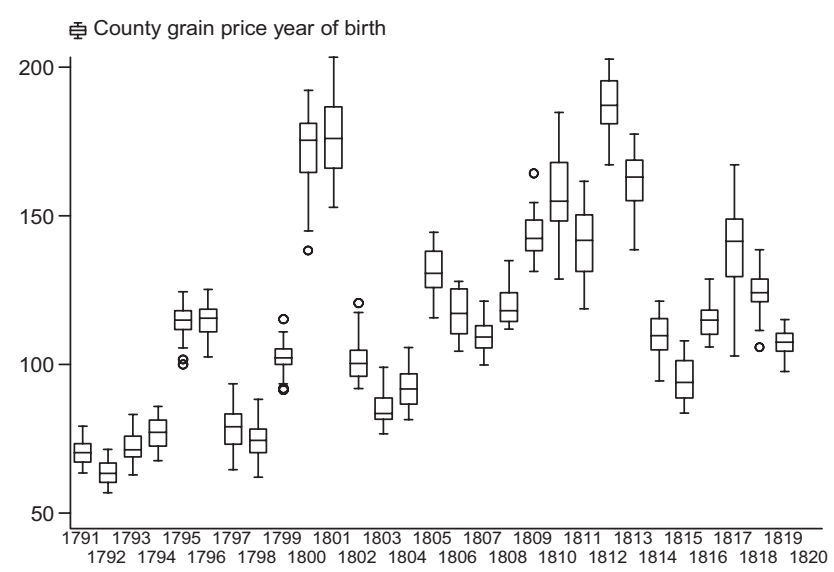

cultural laborer could expect to earn 22 to 35 shillings a year; relief expenditures per recipient ranged from 7 to 19 shillings (Boyer, 1990). Overall, the system cost as much as $2 \%$ of GDP (Mokyr, 1993). Generosity was determined at the parish level, and funding was raised locally. ${ }^{24}$ We use Boyer's (1990) data on relief under the Old Poor Law, supplemented by additional data from his original source. ${ }^{25}$

\section{Empirical Results}

In this section, we first demonstrate that across a wide range of samples, from different time periods, countries, and social groups, the tall are also more numerate. We then document that numeracy fell precipitously among cohorts

\footnotetext{
${ }^{24}$ Economic factors partly explain differences in generosity. Some regions had much greater incentives than others to retain a large number of able-bodied poor to help with the harvest. In the empirical analysis, we control for these factors separately (Boyer, 1986).

${ }^{25}$ Table A2 in the appendix contains the data descriptives for our key variables.
}

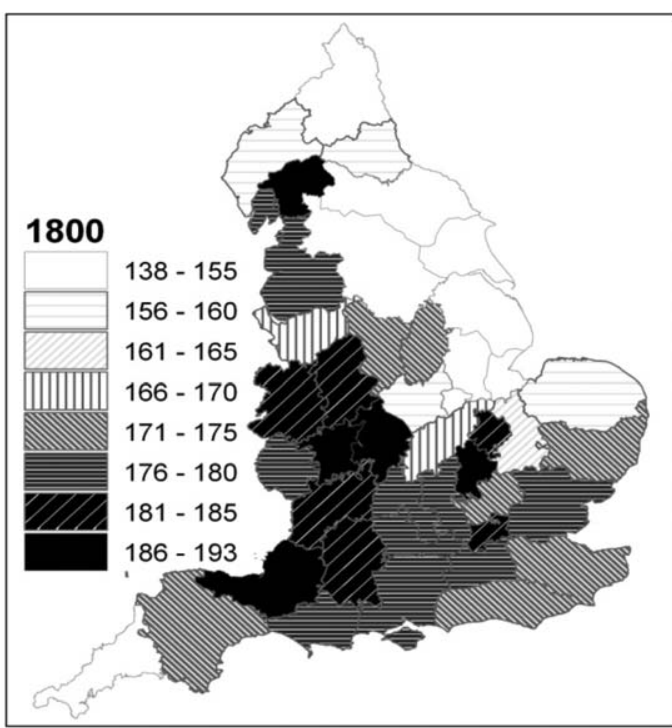

born in industrializing England when grain prices surged as a result of the Napoleonic wars. We do so using the Whipple index for our baseline estimation. Declines in numeracy were particularly pronounced in counties where grain prices were particularly high and income support for the poor was less generous.

Next, we exploit short-term variation, using a variation of the Myers index of age heaping. We show important nonlinearities in the effect of high grain prices on numeracy. In addition, we demonstrate that nutritional status, as proxied by English height, is correlated with numeracy. The part of the variation in heights in our sample driven by grain price shocks predicts age heaping to a significant extent, which strengthens the case for nutritional shortages harming cognitive development. Did any of these effects matter for labor market outcomes? This is the question we address in the final section, where we demonstrate that the malnourished sorted into occupations with lower earnings. $^{26}$

First, we turn to the basic link with nutrition, and examine heights, which capture cumulative nutritional status since childhood (Floud, Wachter, \& Gregory, 1990). Wellnourished individuals stand a better chance of reaching their genetic potential in terms of height. In table 1, we present data from the United States, France, Ireland, and the United Kingdom from the 1660 s to the 1840 s. The samples are divided into tall and short, according to whether individuals' heights are above or below the median. We then calculate Whipple indices for both groups. Throughout, the tall are less likely to misreport their age. In some cases, the difference is small. In other cases, such as the Irish prisoners sent to Australia, and French army recruits from Paris, the

\footnotetext{
${ }^{26}$ A large number of factors unrelated to cognitive ability, such as schooling, changing cultural norms, and bureaucratization, have the potential to influence age-awareness.
} 
Table 1.-Stature And Whipple Ratios

\begin{tabular}{|c|c|c|c|c|c|c|}
\hline \multirow[b]{2}{*}{ Country/Region } & \multirow[b]{2}{*}{ Birth Decade } & \multicolumn{2}{|c|}{ Average Height (inches) } & \multicolumn{2}{|c|}{ Whipple Index } & \multirow[b]{2}{*}{$P$-Value Logit } \\
\hline & & Short & Tall & Short & Tall & \\
\hline England (Wandsworth Prison) & $1800-1840$ & 62.65 & 67.11 & 133 & 129 & 0.764 \\
\hline Ireland (deportees) & $1790-1810$ & 63.65 & 67.71 & 160 & 131 & 0.004 \\
\hline United States (recruits) & $1800-1830$ & 65.76 & 69.81 & 126 & 114 & 0.021 \\
\hline France-Paris (recruits) & $1660-1760$ & 61.50 & 64.06 & 145 & 102 & 0.000 \\
\hline France-northeast (recruits) & $1660-1760$ & 61.97 & 64.60 & 126 & 121 & 0.212 \\
\hline France-southwest (recruits) & $1660-1760$ & 61.39 & 63.94 & 142 & 123 & 0.000 \\
\hline France-total & $1660-1760$ & 61.51 & 64.08 & 135 & 123 & 0.000 \\
\hline
\end{tabular}

Figure 5.-Median Whipple Indices over Time, by Generosity of Poor Relief

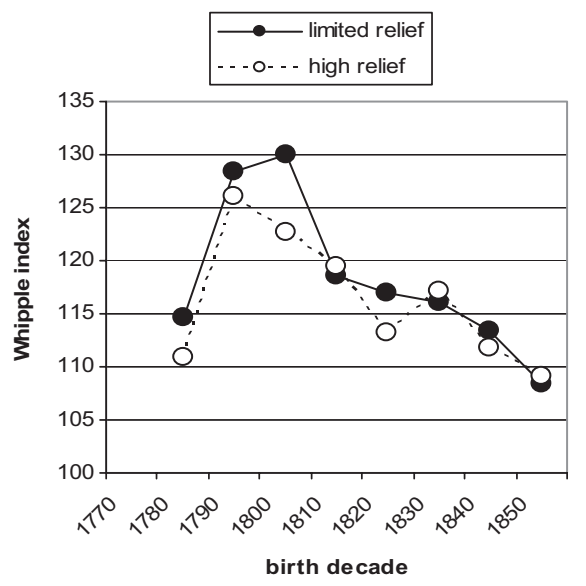

differences are marked, with Whipple indices that are $20 \%$ to $40 \%$ percent higher for the shorter group than for the taller one. ${ }^{27}$ Since the samples are drawn from relatively homogeneous backgrounds, this strengthens the case in favor of a link between nutrition and our indicator of cognitive ability, age heaping. ${ }^{28}$

\section{A. Baseline Results}

Did years of high prices affect numeracy? Figure 5 plots the median Whipple indices over time. After the outbreak of the Napoleonic wars, Whipple indices rose sharply. Starting from very low levels in the 1780 s, median scores reach their highs for the sample in the 1790s and 1800s125 to 130 . The rise in Whipple scores is apparent in counties with both above- and below-average levels of poor relief, but counties with limited relief show a greater and more sustained rise. There, Whipple scores stayed elevated in the 1800 s, while they were already declining in the more generous counties. While not conclusive proof that the poor in parishes with low-income support suffered worse

\footnotetext{
${ }^{27}$ In a logit regression (with the dependent variable equal to unity if no rounded age is reported) on a dummy variable "taller than average," we obtain a significant coefficient (table 1, column 7).

${ }^{28}$ In his analysis of nineteenth-century Bavarian conscripts, Schuster (2005) finds that individuals with exceptionally low intelligence were heavily concentrated among the shortest recruits.
}

declines in nutritional status, harming children's cognitive development, the pattern in the cross-section and over time is consistent with such an interpretation.

Next, we examine these patterns econometrically. We estimate

$$
W_{i, t}=a+\phi S_{i, t}+\beta G_{i, t}+\gamma X_{i, t}^{\prime}+\varepsilon
$$

where $W_{i, t}$ is the Whipple index for county $i$ at time $t, a$ is the intercept (which is county-specific in some of our specifications), $S$ is an indicator variable for the gender of the individuals in each group, $G_{i, t}$ is the grain price in county $i$ at time $t$, and $X^{\prime}$ is a vector of controls (including for a dummy variable for the census year from which the age information is drawn).

Table 2 shows OLS and quantile regressions, with the Whipple index by birth decade, gender, and county as the dependent variable. Wheat prices by the same decades and counties, and relief generosity serve as explanatory variables. Higher grain prices are consistently and strongly associated with greater age heaping in our sample. On average, a 1 standard deviation increase in county wheat prices is associated with a Whipple index that was higher by 2 to 2.5 points (regressions 1-3). ${ }^{29}$ Counties with generous relief (above the median of payments per capita) had Whipple scores that were lower by 2.5 points (regression 2). Instead of the simple dichotomous variable that codes counties as generous or not, in regressions 3 to 5 , we use a continuous transformation of the poor relief variable. This allows us to test if numeracy was consistently lower in parishes where relief payments were smaller. We define Relieflack as $\left[R_{\max }-R_{i}\right]$, where $R_{\max }$ is the highest relief payment per capita recorded in any county, and $R_{i}$ is the relief payment in county $i$. It therefore captures the difference in relief payments in any one county relative to the most generous one (Sussex in 1810) in our sample. We find that lack of poor relief consistently and strongly predicts higher Whipple scores. The continuous measure of poor relief generosity does not undermine the size and significance of the grain price variable. The effect was big.

\footnotetext{
29 Because our data are highly aggregated, the true effects must be substantially larger. Below, we show that even for these point estimates, the income and labor market effects of the grain price on cognitive ability relationship are substantial.
} 
Table 2.-Pooled Regression Analysis: Whipple Scores and Grain Prices DEPENDENT VARIABLE: WhIPPLE INDEX

\begin{tabular}{|c|c|c|c|c|c|c|c|c|c|}
\hline $\begin{array}{l}\text { Regression Estimation } \\
\text { Method }\end{array}$ & $\begin{array}{l}(1) \\
\text { OLS }\end{array}$ & $\begin{array}{c}(2) \\
\text { OLS }\end{array}$ & $\begin{array}{l}(3) \\
\text { OLS }\end{array}$ & $\begin{array}{l}(4) \\
\text { OLS }\end{array}$ & $\begin{array}{c}\text { (5) } \\
\text { Quantile }\end{array}$ & $\begin{array}{l}\text { (6) } \\
\text { OLS }\end{array}$ & $\begin{array}{l}(7) \\
\text { OLS }\end{array}$ & $\begin{array}{c}\text { (8) } \\
\text { Quantile }\end{array}$ & $\begin{array}{c}\text { (9) } \\
\text { Quantile }\end{array}$ \\
\hline County grain price & $\begin{array}{l}0.107^{* * * *} \\
(4.98)\end{array}$ & $\begin{array}{l}0.115^{* * * *} \\
(4.86)\end{array}$ & $\begin{array}{l}0.127 * * * \\
(5.59)\end{array}$ & & $\begin{array}{l}0.120 * * * \\
(4.28)\end{array}$ & $\begin{array}{l}0.067 * * * \\
(3.35)\end{array}$ & $\begin{array}{l}0.078^{* * * *} \\
(4.14)\end{array}$ & $\begin{array}{l}0.082 * * * \\
(3.66)\end{array}$ & $\begin{array}{l}0.096^{* * *} \\
(2.92)\end{array}$ \\
\hline Female & $\begin{array}{l}-1.333 \\
(-1.63)\end{array}$ & $\begin{array}{l}-1.309 \\
(-1.59)\end{array}$ & $\begin{array}{l}-1.300 \\
(-1.55)\end{array}$ & $\begin{array}{l}-1.402 \\
(-1.70)\end{array}$ & $\begin{array}{c}0.100 \\
(0.09)\end{array}$ & $\begin{array}{l}-0.630 \\
(-0.87)\end{array}$ & $\begin{array}{l}-0.604 \\
(-0.81)\end{array}$ & $\begin{array}{l}-0.503 \\
(-0.54)\end{array}$ & $\begin{array}{l}0.062 \\
(0.05)\end{array}$ \\
\hline Reliefhigh & & $\begin{array}{l}-2.517 * * \\
(-2.15)\end{array}$ & & & & $\begin{array}{l}-1.963 * \\
(-1.96)\end{array}$ & & & \\
\hline Relieflack & & & $\begin{array}{l}5.118 * * * \\
(3.25)\end{array}$ & $\begin{array}{l}4.549 * * * \\
(2.79)\end{array}$ & $\begin{array}{l}3.551^{*} \\
(1.86)\end{array}$ & & $\begin{array}{l}4.732 * * \\
(3.40)\end{array}$ & $\begin{array}{l}3.834 * * \\
(2.55)\end{array}$ & $\begin{array}{l}7.550 * * \\
(2.67)\end{array}$ \\
\hline National Grain Price & & & & $\begin{array}{l}0.106^{* * * *} \\
(4.20)\end{array}$ & & & & & \\
\hline Interaction County Grain & & & & & & & & & $0.058 * * *$ \\
\hline Price $\times$ Vulnerability & & & & & & & & & $(2.62)$ \\
\hline Vulnerability & & & & & & & & & $\begin{array}{l}-16.55 \\
(-1.54)\end{array}$ \\
\hline Constant & $\begin{array}{l}108.4 * * * \\
(52.02)\end{array}$ & $\begin{array}{l}108.7 * * * \\
(47.44)\end{array}$ & $\begin{array}{l}99.68 * * * \\
(32.19)\end{array}$ & $\begin{array}{l}102.6 * * * \\
(28.97)\end{array}$ & $\begin{array}{l}99.63 \text { *** } \\
(23.03)\end{array}$ & $\begin{array}{l}115.4 * * * \\
(59.59)\end{array}$ & $\begin{array}{l}107.3 * * * \\
(38.98)\end{array}$ & $\begin{array}{l}103.3 * * * \\
(30.20)\end{array}$ & $\begin{array}{l}103.0 * * * \\
(12.16)\end{array}$ \\
\hline Census fixed effects & No & No & No & No & No & Yes & Yes & Yes & No \\
\hline$N$ & 309 & 309 & 302 & 310 & 302 & 372 & 365 & 365 & 302 \\
\hline Adjusted $R^{2}$ & 0.065 & 0.084 & 0.098 & 0.069 & & 0.177 & 0.197 & & \\
\hline
\end{tabular}

$t$-statistics based on standard errors clustered at the county level, in parentheses. ${ }^{*} p<0.10,{ }^{* *} p<0.05,{ }^{* * *} p<0.01$. The dependent variable is the Whipple score by birth county, gender, and birth decade (177988, 1789-1808 ... 1849-58). We use the national $2 \%$ sample of the 1851 British census, created by Michael Anderson (1987). The data are available at http://www.data-archive.ac.uk/, and, more recently and in standardized form, from North Atlantic Population Project and Minnesota Population Center. NAPP: Complete Count Microdata. NAPP Version 2.0 [computer files]. Minneapolis, MN: Minnesota Population Center [distributor], 2013. http://www.nappdata.org. Schurer and Woollard (2002) produced the 5\% national sample of the 1881 British Census. Main explanatory variables (sources in text and appendix) are the grain price by tributor], 2013. http://www.nappdata.org. Schurer and Woollard (2002) produced the $5 \%$ national sample of the 1881 British Census. Main explanatory variables (sources in text and appendix) are the grain price by
county and year for the same years; Female is a dummy that equals 1 if the observation refers to the females in a county and birth decade. Relief (another dummy) $=1$ if relief payments in a county and decade are above average. Relieflack is $\left[R_{\max }-R_{\mathrm{i}}\right]$, where $R_{\max }$ is the maximum relief payment per capita and $R_{\mathrm{i}}$ is the relief payment in county $i$. National grain price is the average of all county grain prices by decade.

According to our results, the average county in our sample. With a relieflack measure of 1.34 , the average county had Whipple scores that were six to seven points higher than the most generous ones. In regression 4 , we also use the national grain price index instead of the county one, which yields very similar results. ${ }^{30}$

Regression 5 uses a quantile regression, which minimizes the mean absolute deviations instead of the square of deviations. The influence of outliers is thus reduced. We still find similar effects for County Grain Price and Relieflack, evaluated at the median. We also explore responses across the range of the dependent variable. Figure A3 in appendix B plots the coefficients for Relieflack and County Grain Price, for different points in the distribution of the dependent variable (Whipple score). In both cases, as we examine higher and higher conditional percentiles, the effect of the explanatory variables rises. At the 80 th percentile, for example, a 1 standard deviation increase in Relieflack goes hand-in-hand with a Whipple that is 3 points higher (versus 1 at the median). Similarly, at the 80th percentile, a 1 standard deviation rise in the grain prices pushes up the Whipple by 3.5 (which accounts for about $40 \%$ of the standard deviation of the Whipple Index; see table A1 in appendix A); at the median, the effect is 2.4. In regressions 6 to 8 , we disaggregate not

\footnotetext{
${ }^{30}$ All standard errors are clustered at the county level. One strategy applied here to reduce potential problems of endogeneity is to use the national grain price because it is less likely to be endogenously influenced by county-specific developments. However, as the impact of price shocks is predetermined at the time age heaping is observed, endogeneity is probably not an important issue here. The working paper version of this paper contains IV-evidence reinforcing this conclusion (Baten, Crayen, \& Voth 2007).
}

only by county, birth decade, and gender but also by census year. This allows us to include a census fixed effect. The number of observations is slightly larger than in regressions 1 to 5 , whereas the number of underlying age reports that could be employed to calculate Whipple scores was smaller. This increases measurement error. Including the census fixed effect does not affect the results, compared with regressions 2, 3, and 5: the grain price coefficient is only slightly smaller.

The evidence in table 2 suffers from one important drawback: possible bias from unobserved heterogeneity and the effects of year-specific, unobserved economic shocks. Panel estimation at the county level and time fixed effects can help to overcome the pitfalls of cross-sectional analysis (table A3 in appendix B). Several of our exogenous variables do not vary over time and cannot be used at the same time as fixed effects. Results for panel fixed effects estimation are presented in table A3 in appendix B. The $\hat{\beta}$ 's in the fixed-effects regressions are broadly similar to the OLS results and suggest a rise of 7.5 Whipple points for every 1 standard deviation increase of county grain prices. Without decade fixed effects, the grain price coefficients is smaller (final column). Panel models with time fixed effects are preferable because they capture unobserved decade-specific effects. Results are unaffected if we use county-specific controls (regression 5), such as population density, whether an area is grain growing, and the presence of cottage industry. These additional variables are available only for the southern counties in our data set; the number of observations declines when we use them. Additional labor market opportunities (cottage industry) had no clear-cut effect on numeracy. The same is true of living in a grain-growing 
Table 3.-High Frequency Analysis: Grain Prices and Incorrect Age Reporting Dependent Variable: Residual Variable

\begin{tabular}{|c|c|c|c|c|c|}
\hline & (1) & (2) & (3) & (4) & (5) \\
\hline County grain price & $\begin{array}{l}0.090 * * * \\
(5.07)\end{array}$ & $\begin{array}{l}0.050 * * \\
(2.00)\end{array}$ & $\begin{array}{l}-0.599 * * * \\
(-6.80)\end{array}$ & $\begin{array}{l}0.072 * * * \\
(4.27)\end{array}$ & $\begin{array}{l}0.094 * * * \\
(4.06)\end{array}$ \\
\hline Female & $\begin{array}{l}-0.009 \\
(-0.61)\end{array}$ & $\begin{array}{l}-0.005 \\
(-0.35)\end{array}$ & $\begin{array}{l}-0.005 \\
(-0.35)\end{array}$ & $\begin{array}{l}-0.006 \\
(-0.42)\end{array}$ & $\begin{array}{l}-0.001 \\
(-0.05)\end{array}$ \\
\hline Relieflack & $\begin{array}{l}0.026^{*} \\
(1.88)\end{array}$ & & & & \\
\hline Extremely high grain price & & $\begin{array}{l}0.041^{*} \\
(1.77)\end{array}$ & & & \\
\hline County grain price ${ }^{2}$ & & & $\begin{array}{l}0.694 * * * \\
(7.48)\end{array}$ & & \\
\hline Grain & & & & & $\begin{array}{l}0.102 * * * \\
(4.62)\end{array}$ \\
\hline Density & & & & & $\begin{array}{c}0.029 \\
(1.22)\end{array}$ \\
\hline Cottage industry & & & & & $\begin{array}{l}0.100 * * * \\
(5.08)\end{array}$ \\
\hline County FE & No & No & No & Yes & No \\
\hline$N$ & 4,180 & 4,290 & 4,290 & 4,290 & 2,317 \\
\hline Adjusted $R^{2}$ & 0.008 & 0.008 & 0.022 & 0.065 & 0.022 \\
\hline
\end{tabular}

Standardized beta coefficients; $t$ statistics in parentheses. ${ }^{*} p<0.1,{ }^{* *} p<0.05,{ }^{* * *} p<0.01$

area. Wealth is the average value of real estate per capita (Boyer, 1990). It is associated with higher Whipple scores.

Columns 3 to 5 show panel regression results, using poor relief as an additional explanatory variable. We find strongly positive results for the lack of poor relief if we use time dummies. If we use time and county dummies, we obtain a wrongly signed and insignificant result for Relieflack. In estimating the effect of Relieflack, all the important identifying variation is captured by the time and county dummies. In regression 5 , we use additional controls for county characteristics. In this specification, the coefficient on Relieflack is large, positive, and significant. Importantly, the significance of the coefficient for grain prices is never affected.

\section{B. High-Frequency Analysis and the Effect of Nonlinearities}

If our premise is right that nutritional shocks impede cognitive development and undermine the acquisition of numeracy, then this should matter most in years of extreme shortfalls. To examine this further, we first use an additional indicator designed to capture short-term changes in age misreporting. Second, we construct a measure of economic vulnerability from county characteristics and show that in counties with more vulnerable individuals, nutritional shocks mattered a great deal more.

To conduct high-frequency analysis, we use an adaptation of the Myers index, which calculates deviations from an expected age distribution. Typically used on a decade basis, it can be applied to individual birth years. For each county, we fit a linear trend to the distribution of reported ages. Then for each birth year, we use the absolute value of the residual as a measure of age misreporting. Values range from 0 to 45 , while the decade-based Whipple index varies from circa 100 to around 135 . Next, we analyze how nutritional shocks influenced this measure of numeracy.

Figure A4 in appendix B gives an overview of the variable's short-term movements and how they correlate with national grain prices. We plot the residual of the age distribution regressions alongside the grain prices. The correlation is not perfect, but the large spikes largely coincide. The crisis year of 1800-01, in particular, shows a high degree of co-movement, and the sequence of bad harvests from 1810 to 1812 also coincides with a major jump in age misreporting. In figure A5 in appendix B, we show how this effect unfolded in the cross-section, at the height of the crisis in 1800: wherever grain prices were unusually high, the error rate implicit in our residual variable is markedly greater too.

Next, we examine the extent to which this co-movement in the aggregate is statistically significant. To exploit the high-frequency variation in the new short-term dependent variable (also called residual variable below), we now perform regression analysis along the lines of that conducted earlier with the Whipple index (table 3 ). A naive regression (without county fixed effects) of the residual variable on county-specific grain prices yields a large and significant coefficient. When we add a variable for unusually high grain prices (in the top quintile of prices, column 2), this is also associated with an additional increase in the error rate of age reporting among respondents. In column 3, we explore the potential for a nonlinear relationship further by introducing a quadratic term (County Grain Price ${ }^{2}$ ). As the predicted values (figure A7 in appendix D) show, the net effect of higher grain prices turns positive (i.e., detrimental) - and becomes large in exponential fashion, above grain prices of 100 . In column 4 , we estimate including county fixed effects and again obtain a large and significant coefficient. When using county-specific characteristics (column 
Figure 6.-Kernel Density Estimates: Numeracy in Counties with above or Below Median Heights

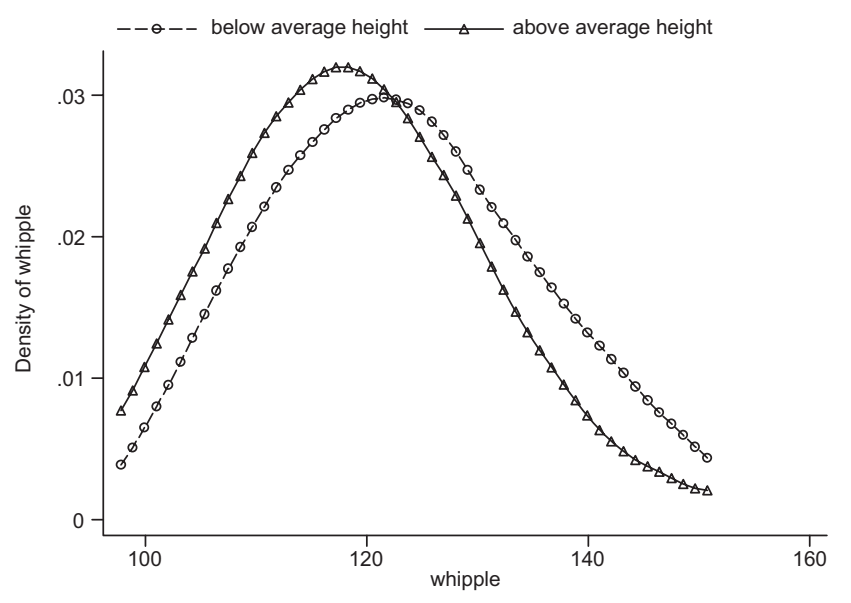

5), we again find the same effect. As a general consequence of high grain prices, areas with substantial grain production saw a bigger rise in the number of incorrectly reported ages.

To examine the issue of nonlinearities further, we do two things. First, we run a quantile regression with County Grain Price (at the year of birth), a dummy for Female respondents, and Relieflack as explanatory variables. We then plot the size of the coefficient on County Grain Price and Relieflack for every percentile of the distribution of reporting errors. The results are summarized in figure A6 in appendix B. At the lower end of the misreporting distribution, the effect of both Relieflack and County Grain Price is small and statistically insignificant. However, the bigger the reporting errors, the stronger is the influence of the two variables that capture hard times in our data.

Second, in appendix D, we examine if high grain prices during the years of the most rapid physical growth had a disproportionate impact on numeracy. Humans go through two major growth spurts in their life: early childhood and the teenage years. We use a standard weighting scheme (YASSISYearly Average Sex and Age Specific Increase in Stature; Coll, 1998). If it is indeed the case that cognitive development is also most sensitive during these periods, we expect an additional effect during the second decade of life, which adds to the strong effect of the first life years (Lenroot \& Giedd, 2006; Paxson \& Schady, 2007). As table A6 in appendix D shows, there is ample evidence that grain prices, weighted to account for the speed of human development by age, have greater predictive power than grain prices in the year of birth only. Based on beta-standardized coefficients, we find that the grain price variable (with YASSIS weighting) is about $50 \%$ larger than the unweighted county grain price. In combination, these findings show that there is not only a negative effect of nutritional shortages on numeracy; the effect also increases in a nonlinear fashion in years of extreme distress, for shocks that hit the same individual multiple times, and for larger shocks than normal.
Table 4.-Heights and Numeracy

Panel Regressions; Dependent Variable: Whipple Index

\begin{tabular}{|c|c|c|c|}
\hline & (1) OLS & (2) OLS & (3) OLS \\
\hline \multirow[t]{2}{*}{ Height } & $-0.820^{*}$ & $-0.612 *$ & 0.025 \\
\hline & $(-1.86)$ & $(-1.83)$ & $(0.07)$ \\
\hline \multirow[t]{2}{*}{ Constant } & $261.4^{* *^{*} *}$ & $220.1^{* *_{*}^{*}}$ & 107.3 \\
\hline & $(3.46)$ & (3.95) & (1.65) \\
\hline Year FE & No & Yes & Yes \\
\hline County FE & No & No & Yes \\
\hline$N$ & 134 & 134 & 134 \\
\hline Adjusted $R^{2}$ & 0.024 & 0.227 & 0.276 \\
\hline
\end{tabular}

\section{Vulnerability}

We now define a socioeconomic measure of vulnerability based on an income threshold. We then examine if counties in the United Kingdom containing an unusually high number of economically vulnerable people were more affected by price increases. For each respondent, we impute earnings based on the reported occupation, using information from Long (2006) and Williamson $(1980,1982)$. We defined a person as vulnerable if he or she had less than the median income ( 47 shillings per year). This covers the unskilled and semiskilled working class. Bakers, butchers, farmers with their own land, and those with higher incomes were less vulnerable.

We created a dummy variable for districts with a more than average number of vulnerable persons. In column 9 of table 2 the interaction term has an additional and significant effect of the expected direction. This suggests that more vulnerable counties suffered more from grain price shocks. Vulnerability per se, in contrast, is insignificant.

\section{Heights}

The previous section demonstrates that individuals born in periods of high prices were, on average, less likely to remember their age correctly. The same is true if they were born in parishes where poor relief payments were limited and vulnerability was higher. One crucial element in our analysis is missing so far: evidence that nutrition (or the lack thereof) drove changes in numeracy. Height is known to be a good indicator of net nutritional status between conception and age 25 . We use data at the county level derived from military heights. In this section, we show that numeracy was systematically lower in parishes where heights declined during the period 1790 to 1815 .

As a first pass, we examine the relationship graphically. Figure 6 plots the distribution of Whipple scores for two groups of counties: those with above- and below-average heights. As we would expect if nutrition influenced both stature and numeracy, counties with above-average heights had lower Whipple scores. Next, we examine this relationship econometrically (table 4). In regressions 1 to 3, greater height in county $i$ at time $t$ is associated with lower Whipple scores. In other words, men and women from English counties with low stature on average made more mistakes reporting their ages. The effect can be large-up to 2 Whipple 


\begin{tabular}{|c|c|c|c|c|c|c|}
\hline \multicolumn{7}{|c|}{$\begin{array}{l}\text { TABLE 5.-EARNINGS AND NuMERACY } \\
\text { (IV-PANEL REGRESSIONS) } \\
\text { DEPENDENT VARIABLE: LOG EARNINGS }\end{array}$} \\
\hline & (1) & (2) & (3) & (4) & (5) & (6) \\
\hline \multirow[t]{2}{*}{ Whipple } & $-0.0080^{* * * *}$ & $-0.0073^{* * * *}$ & $-0.0199^{* * *}$ & -0.0016 & $-0.0065^{* * *}$ & 0.0029 \\
\hline & $(-3.33)$ & $(-2.72)$ & $(-8.73)$ & $(-0.46)$ & $(-2.83)$ & $(1.14)$ \\
\hline \multirow[t]{2}{*}{ Female } & $-0.461^{* * *}$ & $-0.459^{* * *}$ & $-0.463^{* * *}$ & $-0.459^{* * *}$ & $-0.459^{* * *}$ & $-0.454^{* * *}$ \\
\hline & $(-17.55)$ & $(-15.90)$ & $(-15.75)$ & $(-15.47)$ & $(-15.30)$ & $(-14.61)$ \\
\hline \multirow[t]{2}{*}{ Constant } & $5.273^{* * * *}$ & $5.199^{* * *}$ & $6.599^{* * * *}$ & $4.525^{* * * *}$ & $5.107^{* * * *}$ & $3.897^{* * * *}$ \\
\hline & $(19.24)$ & $(17.22)$ & $(26.66)$ & $(11.86)$ & $(19.90)$ & $(12.87)$ \\
\hline County FE & No & Yes & Yes & No & Yes & Yes \\
\hline Year FE & No & No & Yes & No & No & Yes \\
\hline Instrument & National Grain Price & National Grain Price & National Grain Price & County Grain Price & County Grain Price & County Grain Price \\
\hline$N$ & 243 & 255 & 255 & 247 & 247 & 247 \\
\hline
\end{tabular}

points for a standard deviation change in heights. The effect is large and significant when we include time dummies; it falls below conventional significance levels once we include both time and county dummies.

\section{Discussion}

In this section, we examine the overall economic impact of war-induced lack of numeracy. We also discuss potential limitations of our argument.

\section{A. Economic Impact}

Did the nutritional shocks during the American Revolutionary and Napoleonic wars matter for economic outcomes? To answer this question, we examine if there were negative consequences for earnings. We use information on the occupation of each individual in the 1851 and 1881 census data files and calculate imputed earnings for each birth cohort by county based on their reported occupation (Long, 2006; Williamson, 1980, 1982). We regress earnings on the Whipple index, instrumented by the national and county grain prices. Table 5 shows the results. Regression 1 indicates that higher Whipple scores went hand-in-hand with lower earnings. A 1 standard deviation gain in the Whipple was associated with a $1.9 \%$ decline in earnings (relative to the median). Regressions 2 and 3 show that the effect is robust to including county and decade fixed effects. If we control for time and county fixed effects, a 1 standard deviation rise in numeracy increased earnings by $3.3 \%$. If we use county grain prices as the instrument instead, the effect is weaker (except for regression 5); in regression 6, the coefficient becomes positive. Remarkably, the detrimental effects of the Napoleonic wars remained visible in earnings for many decades. Overall, lower numeracy was partly responsible for translating the adverse shock of the wars into lower earnings.

\section{B. Potential Limitations}

The decline in numeracy was concentrated during the American Revolution and Napoleonic wars. We cannot completely rule out that other factors-to the extent that they are correlated with the generosity of poor relief-were responsible for our results in the cross section. Britain fought a war that required major military, fiscal, and economic mobilization. Theoretically, the absence of fathers or a decline in school attendance could also cause lower numeracy. ${ }^{31}$ Neither is a likely explanation for this period: few men of marriageable ages served, and the acquisition of basic skills took place outside day schools before the 1870s (Mitch, 1992). Schofield (1973) found that illiteracy rates for men and women were broadly stable or gradually declining between 1750 and 1840; there is no evidence of a sudden fall in signature rates during the Napoleonic wars (Nicholas \& Nicholas, 1992).

\section{Conclusion}

In this paper, we exploit a quasi-natural experiment: when industrializing Britain went to war with France in the 1790s, grain imports from the Continent were sharply curtailed for many years. Market integration within Britain declined as privateers preyed on coastal shipping. Prices for wheat and other staples surged, especially during years with poor harvests. We examine the impact of these exogenous shocks on food availability and show that they lowered average numeracy. Our findings are among the first to demonstrate that large economic shocks can have deleterious effects on cognitive ability. ${ }^{32}$

We show that subjects born in the hungry decades of the 1790 s and 1800 s were much less likely to remember their age correctly or to perform the calculation necessary to derive it without error. The detrimental effect of high food prices was particularly pronounced in areas that did little to help the poor, increased in exponential fashion, and was greatest in areas of economic vulnerability. We demonstrate that numeracy declined sharply where nutritional intake, as measured by

\footnotetext{
31 This would be in line with recent work by Miguel and Kremer (2004).

${ }^{32}$ The paper closest in spirit to ours is Alderman et al. (2006), where the effects of war are also apparent in educational outcomes and test scores.
} 
average heights, declined the most. This strengthens the case for a link between nutrient availability and cognitive development as reflected in age heaping. In addition, the food crisis of the war years also affected the careers of those in their infancy when high grain prices hit. They selected into occupations that were less demanding on average in terms of cognitive skills, earning less than their peers.

England operated an early and unusually comprehensive system of income support (Boyer, 1990). Individuals from areas hit by particularly high prices, and without much income support, showed particularly low numeracy: the "first welfare state" was effective in improving the lives of the poor. ${ }^{33}$ While social disruptions during the Napoleonic wars reduced schooling, it is more likely that lower cognitive ability, driven by poor nutrition, was the main factor behind lower numerical ability.

How relevant are our findings to other periods and countries? Englishmen and -women during the early modern period were unusually well nourished (Fogel, 1994); England is the only European country where food fantasies play no role in popular fairy tales. This suggests that average nutrition was poorer elsewhere and that shocks there would have had even more dramatic effects. It seems plausible that nutritional deficiencies constrained cognitive development for much of human history.

Life in the past was not only "nasty, brutish, and short," in the words of Thomas Hobbes; people in the past may have been ignorant because they were often poor and hungry. Yet causation may also have flowed the other way: output may have been low because of low cognitive ability. ${ }^{34}$ While we offer no direct proof, improved nutrition and higher cognitive ability after 1800 may well have fostered the transition to self-sustaining growth in industrializing Europe. ${ }^{35}$

\footnotetext{
${ }^{33}$ The importance of average incomes in general, and of England's income support in particular, is explored in Voigtländer and Voth (1996).

${ }^{34}$ In this way, our research complements the argument by Fogel (1994) who argued that better nutrition led to higher productivity over the past 200 years because it increased strength. Cognitive ability is a crucial factor not emphasized in his interpretation.

${ }^{35}$ There are also possible implications for the more recent past. Flynn (1984) showed that cognitive scores underlying IQ tests were rising for several decades in the twentieth century. Between 1930 and 1900, average cognitive ability scores rose by the equivalent of 0.6 IQ points per year (Hiscock, 2007). The benefits of higher cognitive scores in the labor market today are well known (Case \& Paxson, 2008). A strong link between nutrition, cognitive ability, and productivity would arguably offer an alternative explanation for the poverty of the past-one that does not have to put store in the slow rise to dominance of a population segment possessing a superior culture, as argued by Clark (2007).
}

\section{REFERENCES}

Abbott, Robert, Lon White, Webster Ross, Helen Petrovitch, Kamal Masaki, David Snowdon, and David Curb, "Height as a Marker of Childhood Development and Late-Life Cognitive Function: The Honolulu-Asia Aging Study," Pediatrics 102 (1998), 602-609.

A'Hearn, Brian, Joerg Baten, and Dorothee Crayen, "Quantifying Quantitative Literacy: Age Heaping and the History of Human Capital," Journal of Economic History 69 (2009), 783-808.
Alderman, Harold, John Hoddinott, and Bill Kinsey, "Long Term Consequences of Early Childhood Malnutrition." Oxford Economic Papers 58 (2006), 450-474.

Almond, Douglas, "Is the 1918 Influenza Pandemic Over? Long-Term Effects of in Utero Influenza Exposure in the Post-1940 U.S. Population," Journal of Political Economy 114 (2006), 672-712.

Almond, Douglas, and Bhashkar Mazumder, "Health Capital and the Prenatal Environment: The Effect of Ramadan Observance during Pregnancy," American Economic Journal: Applied Economics 3, (2011), 56-85.

Anderson, Michael, The 1851 Census: A National Sample of the Enumerators Returns. Cambridge: Chadwyck-Healey.

Bachi, Robert, "The Tendency to Round Off Age Returns: Measurement and Correction." Bulletin of the International Statistical Institute 33 (1951), 195-221.

Baten, Joerg, Dorothee Crayen, and Joachim Voth, "Poor, Hungry and Ignorant: Numeracy and the Impact of High Food Prices in Industrializing Britain, 1780-1850," Universidad Pompeu Fabra Economic working paper 1120 (2007).

Boyer, George, An Economic History of the English Poor Law, 17501850 (Cambridge: Cambridge University Press, 1990).

Brunt, Liam, and Edmund Cannon, "The Truth, the Whole Truth and Nothing But the Truth: The English Corn Returns as a Data Source in Economic History, 1770-1914," European Review of Economic History 17 (2013), 318-339.

Case, Anne, Angela Fertig, and Christina Paxson, “The Lasting Impact of Childhood Health and Circumstance," Journal of Health Economics 24 (2005) 365-389.

Case, Anne, and Christina Paxson, "Stature and Status: Height, Ability, and Labor Market Outcomes," Journal of Political Economy 116 (2008) 499-532.

Census, General Report (British Parliamentary Papers 1893-4, vol. CVI). (London: HMSO, 1891).

General Report on the 1951 Census (Laid before Parliament Pursuant to Section 4 (1), Census Act, 1920) (London: HMSO, 1958).

Chen, Yoyu, and Li-An Zhou, "The Long-Term Health and Economic Consequences of the 1959-1961 Famine in China," Journal of Health Economics 26 (1997), 659-681.

Clark, Gregory, A Farewell to Alms (Princeton, NJ: Princeton University Press, 2007).

Coll, Sebastian, "The Relationship between Human Physical Stature and GDP," in John Komlos and Joerg Baten, eds., The Biological Standard of Living in Comparative Perspective (Stuttgart: Franz Steiner, 1998).

Crayen, Dorothee, and Joerg Baten, "New Evidence and New Methods to Measure Human Capital Inequality before and during the Industrial Revolution," Economic History Review 53 (2010), 452-478.

Currie, Janet, "Healthy, Wealthy, and Wise: Socioeconomic Status, Poor Health in Childhood, and Human Capital Development." Journal of Economic Literature 47 (2009), 87-122.

Currie, Janet, and Rosemary Hyson, "Is the Impact of Health Shocks Cushioned by Socioeconomic Status? The Case of Low Birth Weight," American Economic Review 89 (1999), 245-250.

Cutler, David, Grant Miller, and Douglas Norton, "Evidence on EarlyLife Income and Late-Life Health from America's Dust Bowl Era," Proceedings of the National Academy of Sciences 104 (2007), 13244-13249.

Davies, David, The Case of the Labourers in Husbandry (London, 1795).

Davis, Lance, and Stanley Engerman, Naval Blockades in Peace and War: An Economic History since 1750 (Cambridge: Cambridge University Press, 2006).

Duncan-Jones, Richard, Structure and Scale in the Roman Economy (Cambridge: Cambridge University Press, 1990).

Eden, Frederick Morton, The State of the Poor (London, 1797).

Flynn, James Robert, "The Mean IQ of Americans: Massive Gains 1932 to 1978," Psychological Bulletin 95 (1984), 29-51.

Floud, Roderick, Kenneth Wachter, and Annabel Gregory, Height, Health, and History: Nutritional Status in the United Kingdom, 1750-1980 (Cambridge: Cambridge University Press, 1990).

Fogel, Robert, "Economic Growth, Population Theory, and Physiology," American Economic Review 84 (1994), 369-395.

Galor, Oded, and David Weil, "Population, Technology, and Growth," American Economic Review 90 (2000), 806-828.

Heckman, James, "Review: Lessons from the Bell Curve," Journal of Political Economy 103 (1995), 1091-1120. 
"The Economics, Technology and Neuroscience of Human Capability Formation," Proceedings of the National Academy of Sciences 104 (2007), 13250-13255.

Herlihy, David, and Christiane Klapisch-Zuber, Les Toscans et leurs familles: une étude du catasto florentin de 1427 (Paris : Presses de la Fondation Nationale des Sciences Politiques, 1978).

Higgs, Edward, Making Sense of the Census: The Manuscript Returns for England and Wales, 1801-1901. Public Record Office Handbook No. 23 (London: Her Majesty's Stationery Office, 1989).

Hiscock, Merrill, "The Flynn Effect and Its Relevance to Neuropsychology," Journal of Clinical and Experimental Neuropsychology 29 (2007), 514-529.

Jacks, David, "Foreign Wars, Domestic Markets: England, 1793-1815," European Review of Economic History 15 (2011), 277-311.

Komlos, John, Nutrition and Economic Development in the EighteenthCentury Habsburg Monarchy: An Anthropometric History (Princeton, NJ: Princeton University Press, 1989).

Lenroot, Rhoshel K., and Jay N. Giedd, "Brain Development in Children and Adolescents: Insights from Anatomical Magnetic Resonance Imaging," Neuroscience and Biobehavioural Reviews 30 (2006), $718-729$.

Linnet, Karen Markussen, Kirsten Wisborg, Esben Agerbo, Niels-Jorgen Secher, Per Hove Thomsen, and Tine Brink Henriksen, "Gestational Age, Birth Weight, and the Risk of Hyperkinetic Disorder," Archives of Disease in Childhood 91 (2006), 655-660.

Lloyd-Still, John, "Clinical Studies on the Effects of Malnutrition during Infancy and Subsequent Physical and Intellectual Development," in John Lloyd-Still, ed., Malnutrition and Intellectual Development (Lancaster: Medical and Technical Publishing, 1976).

Long, Jason, "The Socioeconomic Return to Primary Schooling in Victorian England," Journal of Economic History 66 (2006), 10261053.

Lucas, Alan, "Programming by Early Nutrition: An Experimental Approach," Journal of Nutrition 128 (1998), 401S-406S.

Lynn, Richard, and Tatu Vanhanen, IQ and the Wealth of Nations (New York: Praeger, 2002).

Magnusson, Patrik, Finn Rasmussen, and Ulf Gyllensten, "Height at Age 18 Years Is a Strong Predictor of Attained Education Later in Life," International Journal of Epidemiology 35 (2006), 658-663.

Miguel, Edward, and Miguel Kremer, "Worms: Identifying Impacts on Education and Health in the Presence of Treatment Externalities," Econometrica 72 (2004), 159-217.

Mitch, David, The Rise of Popular Literacy in Victorian England: The Influence of Private Choice and Public Policy (Philadelphia: University of Pennsylvania Press, 1992).

"The Role of Education and Skill in the British Industrial Revolution" (pp. 241-279), in Joel Mokyr, ed., The British Industrial Revolution: An Economic Perspective (Boulder, CO: Westview Press, 1998).

Mokyr, Joel, Why Ireland Starved (London: George Allen \& Unwin, 1983).

Mokyr, Joel, and Eugene Savin, "Stagflation in Historical Perspective," Research in Economic History 1 (1976), 198-259.

"Editor's Introduction" (pp. 1-131), in Joel Mokyr, ed., The British Industrial Revolution: An Economic Perspective (Boulder, CO: Westview Press, 1993).

Myers, Robert, "An Instance of Reverse Heaping of Ages," Demography 13 (1976), 577-580.

Neugebauer, Richard, Hans Wijbrand Hoek, and Ezra Susser, "Prenatal Exposure to Wartime Famine and Development of Antisocial Personality Disorder in Early Adulthood," Journal of the American Medical Association 282 (1999), 455-462.

Nicholas, Stephen, and Jacqueline Nicholas, "Male Literacy, 'Deskilling,' and the Industrial Revolution," Journal of Interdisciplinary History 23 (1992), 1-18.
Olson, Mancur, The Economics of Wartime Shortage (Durham, NC: Duke University Press, 1963).

Paxson, Christina, and Norbert Schady, "Cognitive Development among Young Children in Ecuador," Journal of Human Resources 42 (2007), 49-84.

Persico, Nicola, Andrew Postlewaite, and Dan Silverman, "The Effect of Adolescent Experience on Labor Market Outcomes: The Case of Height." Journal of Political Economy 112 (2004), 10191053.

Pollitt, Ernesto, Kathleen S. Gorman, Patrice L. Engle, Reynaldo Martorell, and Juan River, Early Supplementary Feeding and Cognition: Effects over Two Decades (Chicago: University of Chicago Press, 1993).

Richards, Marcus, Rebecca Hardy, Diana Kuh, and Michael Wadsworth, "Birth Weight, Postnatal Growth and Cognitive Function in a National UK Birth Cohort," International Journal of Epidemiology 31 (2002), 342-348.

Richards, Marcus, and Michael Wadsworth, "Long-Term Effects of Early Adversity on Cognitive Function," Archive of Disease in Childhood 89 (2004), 922-927.

Rivera-Batiz, Francisco, "Quantitative Literacy and the Likelihood of Employment among Young Adults in the United States," Journal of Human Resources 27 (1992), 313-328.

Schofield, Robert, "Dimensions of Illiteracy, 1750-1850," Explorations in Economic History 10 (1973), 437-454.

Schurer, Kevin, and Matthew Woollard, National Sample from the 1881 Census of Great Britain (Colchester: University of Essex, and Salt Lake City: Genealogical Society of Utah, 2002).

Schuster, K., Wirtschaftliche Entwicklung, Sozialstruktur und biologischer Lebensstandard in München und dem südlichen Bayern im 19. Jahrhundert (St. Katharinen: Scripta Mercaturae Verlag, 2005).

Steckel, Richard, "Stature and the Standard of Living," Journal of Economic Literature 33 (1995), 1904-1940.

Stein, Zena, and Mervyn Susser, "Prenatal Nutrition and Mental Competence," in John-Lloyd Still, ed., Malnutrition and Intellectual Development (Lancaster: Medical and Technical Publishing, 1976).

Sundet, Jon, Kritian Tambs, Jennifer Harris, Per Magnus, and Tore Torjussen, "Resolving the Genetic and Environmental Sources of the Correlation between Height and Intelligence," Twin Research and Human Genetics 8 (2005), 307-311.

Thomson, David, "Age Reporting by the Elderly and the Nineteenth Century Census," Local Population Studies 25 (1980), 13-25.

Tillot, Peter, "Sources of Inaccuracy in the 1851 and 1861 Censuses" (pp. 82-133), in Edward Wrigley, ed., Nineteenth-Century Society: Essays in the Use of Quantitative Methods for the Study of Social History (Cambridge: Cambridge University Press, 1972).

Vermeersch, Christel, and Michael Kremer, "School Meals, Educational Achievement and School Competition: Evidence from a Randomized Evaluation," World Bank Policy Research working paper 3523 (2004).

Voigtländer, Nico, and Voth, Hans-Joachim, "Why England?" Journal of Economic Growth 11 (2006), 319-361.

Voth, Hans-Joachim, "Living Standards and Urban Disamenities," in Roderick Floud and Paul Johnson, eds., Cambridge Economic History of Britain (Cambridge: Cambridge University Press, 2003).

Waaler, Hans, "Height, Weight and Mortality: The Norwegian Experience," Acta Med. Scand. 679 (1984), 1-56.

Williamson, Jeff, "Earnings Inequality in Nineteenth-Century Britain," Journal of Economic History 40 (1980), 457-475.

"The Structure of Pay in Britain, 1710-1911," Research in Economic History 7 (1982), 1-54.

Zax, Jeffrey, and Daniel Rees, "IQ, Academic Performance, Environment, and Earnings," this REvIEw 84 (2002), 600-616. 